\title{
Behawioralne aspekty zarządzania ryzykiem w polskich przedsiębiorstwach w świetle badań ankietowych
}

\author{
Dr hab. Izabela Jonek-Kowalska, prof. PŚ \\ Politechnika Śląska, Wydział Organizacji i Zarządzania \\ Katedra Ekonomii i Informatyki
}

\section{Wprowadzenie}

We współczesnym - bardzo burzliwym i zmiennym - otoczeniu podmioty gospodarcze wciąż muszą liczyć się z nowymi okolicznościami prowadzenia działalności gospodarczej ${ }^{1}$. Ich pojawianie się bardzo często generuje nowe źródła ryzyka lub intensyfikuje natężenie i częstotliwość występowania źródeł już rozpoznanych. Wskutek tego zarządzanie ryzykiem staje się procesem coraz trudniejszym i bardziej złożonym. Warto także podkreślić, że na jego przebieg oddziałują nie tylko nieprzewidywalne okoliczności wewnętrzne czy zewnętrzne, ale również personalne charakterystyki menedżerów podejmujących decyzje w zakresie identyfikacji, oceny i doboru metod zarządzania oraz kontroli ryzyka. Ich rozpoznanie pozwala lepiej zrozumieć procesy podejmowania decyzji w zakresie zarządzania ryzykiem oraz określa podstawy ich doskonalenia w celu uzyskania wyższej skuteczności i efektywności².

Mając na uwadze wskazane okoliczności, za główny cel niniejszego artykułu przyjęto identyfikację i charakterystykę czynników behawioralnych w zarządzaniu ryzykiem w polskich przedsiębiorstwach, którą przeprowadzono na podstawie badań ankietowych na reprezentatywnej, losowo wybranej próbie średnich i dużych przedsiębiorstw (łącznie 722 podmioty) w 2019 roku.

1 B.R. Lofstedt, J. Wardman, The changing nature of communication and regulation of risk in Europe, „Journal of Risk Research” 2011, vol. 14, issue 4, s. 409-429; H. Thamhain, Managing risks in complex projects, „Project Management Journal” 2013, vol. 44, s. 20-35.

2 M.F. Malik, M. Zaman, S. Buckby, Enterprise risk management and firm performance: Role of the risk committee, „Journal of Contemporary Accounting \& Economics” 2020, vol. 16, issue 1, nr art. 100178; S. Durst, Ch. Hinteregge, M. Zieba, The linkage between knowledge risk management and organizational performance, „Journal of Business Research” 2019, vol. 105, s. 1-10. 
Takie badania nie były dotąd prowadzone w tak szerokim zakresie, a ich wyniki stanowią poznawcze uzupełnienie wiedzy dotyczącej uwarunkowań zarządzania ryzykiem w polskiej rzeczywistości gospodarczej. Aby tak postawiony cel zrealizować, w kolejnych częściach artykułu przedstawiono charakterystykę trzech kluczowych czynników behawioralnych oddziałujących na proces zarządzania ryzykiem (postrzeganie ryzyka, skłonność do ryzyka i postawy wobec ryzyka) oraz wyniki badań przeprowadzonych w tym zakresie. W dalszej części zaprezentowano metodykę badań wraz z opisem doboru próby badawczej oraz rezultaty badań pozwalające uzyskać odpowiedzi na następujące problemy badawcze:

- Jakie cechy behawioralne w kontekście zarządzania ryzykiem charakteryzują menedżerów w polskich małych i średnich przedsiębiorstwach?

- Czy istnieją różnice w postrzeganiu, skłonności i postawach wobec ryzyka w średnich i dużych przedsiębiorstwach w Polsce?

W zakończeniu podsumowano wyniki, sformułowano rekomendacje dotyczące doskonalenia procesu zarządzania ryzykiem $\mathrm{w}$ polskich przedsiębiorstwach oraz zidentyfikowano kierunki dalszych badań.

\section{Studia literaturowe}

Jak zasygnalizowano we wprowadzeniu, na decyzje podejmowane w procesie zarządzania ryzykiem oddziałują czynniki behawioralne związane z personalnymi charakterystykami decydentów jako zarządzających przedsiębiorstwem. Zalicza się do nich postrzeganie ryzyka, skłonność do podejmowania ryzyka oraz postawy wobec ryzyka 3 .

Postrzeganie ryzyka związane jest z dychotomicznością tego pojęcia. Tradycyjnie i bardzo powszechnie ryzyko kojarzy się z możliwością negatywnego odchylenia planu od rzeczywistości, wywołanego nieprzewidzianymi okolicznościami. Ma więc przede wszystkim negatywne konotacje. Tak też jest pojmowane przez wielu badaczy propagujących defensywny nurt definiowania ryzyka ${ }^{4}$. Tymczasem Drucker zwraca uwagę, że ryzyko może oznaczać także możliwość pozytywnego odchylenia planu od rzeczywistości i szansę uzyskania dodatkowych

3 K. Jędralska, Zachowania przedsiębiorstw w sytuacjach niepewnych i ryzykownych, Wydawnictwo Akademii Ekonomicznej w Katowicach, Katowice 1992, s. 73-77.

4 A. Karmańska, Neoklasyczne ramy analizy atrybutów ryzyka, [w:] A. Karmańska (red.), Ryzyko w rachunkowości, Wydawnictwo Difin, Warszawa 2008, s. 23-58; T.T. Kaczmarek, Ryzyko i zarządzanie ryzykiem. Ujęcie interdyscyplinarne, Wydawnictwo Difin, Warszawa, 2007, s. 50-55; K. Jajuga, T. Jajuga, Inwestycje. Instrumenty finansowe, ryzyko finansowe. Inżynieria finansowa, Wydawnictwo Naukowe PWN, Warszawa 1998, s. 98-99. 
nieprzewidywanych korzyści, a nie tylko możliwość strat ${ }^{5}$. Takie postrzeganie ryzyka, kultywowane w ofensywnym nurcie jego definiowania, pozwala menedżerom podejmować nowe wyzwania oraz wzmacnia ich przedsiębiorczość i innowacyjność 6 .

Z dotychczasowych badań wynika, że postrzeganie ryzyka determinowane jest przez dwie kluczowe okoliczności. Pierwszą z nich jest ogólne nastawienie do życia, które może być pozytywne (optymistyczne) lub negatywne (pesymistyczne). Menedżerowie z pozytywnym nastawieniem życiowym częściej traktują ryzyko jako szansę i wyzwanie, które należy podjąć w poszukiwaniu dodatkowych korzyści, niż menedżerowie z nastawieniem negatywnym, postrzegający ryzyko jedynie jako zagrożenie związane z nieprzewidywanymi stratami. Drugą okolicznością wpływającą na postrzeganie ryzyka są dotychczasowe doświadczenia związane z jego realizacją7. Jeżeli podejmowanie ryzyka częściej wiązało się z ponoszeniem strat, menedżerowie częściej będą postrzegali je jako zagrożenie, jeżeli zaś częściej było źródłem dodatkowych korzyści, to ich percepcja ryzyka będzie zdecydowanie bardziej optymistyczna. Warto także dodać, że w postrzeganiu ryzyka ważną determinantą jest wiek menedżera. Badania wykazują, że starsi menedżerowie częściej postrzegają ryzyko jako zagrożenie niż ich młodsi koledzy ${ }^{8}$.

Czynnikiem behawioralnym, który bezpośrednio wiąże się z postrzeganiem ryzyka, jest skłonność do jego podejmowania. Można ją określić w kontekście identyfikacji decydenta z następującymi stwierdzeniami: (1) „lubię ryzyko”, (2) „ignoruję ryzyko” albo (3) „unikam ryzyka”. Na skłonność do ryzyka oddziałują indywidualne wzorce radzenia sobie z sytuacjami ryzykownymi oraz wspomniana już historia doświadczeń. Skłonność do ryzyka może zmieniać się w czasie wraz ze zmianą wymienionych wzorców i indywidualnej historii doświadczeń ${ }^{9}$. Należy dodać,

5 P.F. Drucker, Skuteczne zarzqdzanie, PWN, Warszawa 1976, s. 296-298; P.F. Drucker, Zarzqdzanie organizacja pozarządową. Teoria i praktyka, Wydawnictwo Borodo, Warszawa 1995, s. 26-28.

6 Ph. Bromiley i wsp., Enterprise risk management: Review, critique, and research directions, „Long Range Planning” 2014, vol. 11, s. 1-12; M.K. McShane, A. Nair, E. Rustambekov, Does enterprise risk management increase firm value?, „Journal of Accounting, Auditing \& Finance" 2011, vol. 26, no. 4, s. 641-658.

7 A.M. Isen, N. Geva, Influence of positive effect on the subjective utility of gains and losses: It is just not worth the risk, „Journal of Personality and Social Psychology” 1988, vol. 55, s. 710-717; A.M. Isen, R.A. Baron, Positive effect as a factor in organizational behaviour, „Research in Organizational Behavior" 1991, vol. 13, s. 1-53.

8 E.J. Douglas, Perceptions - looking at the world through entrepreneurial lenses, [w:] A.L. Carsrud, M. Brännba (red.), Understanding the Entrepreneurial Mind: Opening the Black Box, Springer, New York 2009, s. 5-25.

9 M. Arena, M. Arnaboldi, G. Azzone, The organizational dynamics of enterprise risk management, „Accounting, Organizations and Society” 2010, vol. 35, no. 7, s. 659-675. 
że ma ona również charakter deklaratywny i nie zawsze pokrywa się z rzeczywistymi postawami wobec ryzyka, realizowanymi w procesie decyzyjnym.

Postrzeganie ryzyka przez menedżerów wpływa bezpośrednio na ich postawy wobec niego ${ }^{10}$. Jeśli decydenci kojarzą ryzyko jedynie z zagrożeniem i stratami, najprawdopodobniej będą go unikać (postawa pasywna, ograniczona do ochrony przed ryzykiem), tracąc jednocześnie szanse i zyski związane z jego podjęciem. Jeżeli natomiast będą postrzegać ryzyko w kontekście pozytywnym, to chętniej zdecydują się na jego podjęcie (postawa aktywna). Ci zaś, którzy ryzyka nie doceniają, pozostaną wobec niego obojętni (ignorancja ryzyka).

Tak rozumiane czynniki behawioralne, osadzone w zaprezentowanym kontekście badawczym, są przedmiotem badań przeprowadzonych wśród polskich średnich i dużych przedsiębiorstw w 2019 roku. Ich wyniki wraz z metodyką badawczą przedstawiono w dalszej części niniejszego artykułu.

\section{Metodyka badań \\ Dobór i charakterystyka próby}

Badania przeprowadzono na reprezentatywnej próbie średnich i dużych przedsiębiorstw, dobranej przy założeniu 95-procentowego poziomu ufności oraz wielkości frakcji na poziomie 0,5. Wielkość populacji małych i średnich przedsiębiorstw oszacowano na podstawie danych Głównego Urzędu Statystycznego za 2017 rok. Adresatami badania byli menedżerowie odpowiedzialni za zarządzanie ryzykiem w danym przedsiębiorstwie lub w przypadku braku takich osób (wyodrębnionych komórek) pracownicy reprezentujących strategiczny szczebel zarządzania przedsiębiorstwem.

Dodatkowo w próbie zastosowano podział na rodzaj prowadzonej działalności, uwzględniający następujące podgrupy:

- produkcja,

- handel,

- usługi,

- budownictwo.

10 T. Tavor, The theoretical attitude and actual behavior of an individual towards risk, „Journal of Behavioral and Experimental Finance" 2019, vol. 23, s. 1-11; M. Jaramillo, K.L. Vargas, Interpersonal comparisons and risk attitudes: An artefactual field experiment, „Economics Letters" 2019, vol. 179, s. 16-18; H.H. Nax, J. Newton, Risk attitudes and risk dominance in the long run, „Games and Economic Behavior” 2019, vol. 116, s. 179-184; F. Tausch, M. Zumbuehl, Stability of risk attitudes and media coverage of economic news, „Journal of Economic Behavior \& Organization" 2018, vol. 150, s. 295-310. 
Ostatecznie w skład próby weszły 722 przedsiębiorstwa, w tym 375 średnich i 347 dużych. Strukturę uwzględniającą wymienione rodzaje działalności w grupie średnich i dużych podmiotów, określoną w losowaniu warstwowym, przedstawiono na rysunkach 1 i 2 .

Zgodnie z rzeczywistą strukturą rodzajów prowadzonej działalności gospodarczej w Polsce w obu grupach badanych przedsiębiorstw dominowała produkcja, przy czym jej udział był wyższy wśród dużych podmiotów. W obu próbach na kolejnych miejscach uplasowały się: usługi, handel i budownictwo, z nieco wyższym udziałem handlu i budownictwa w grupie średnich przedsiębiorstw.

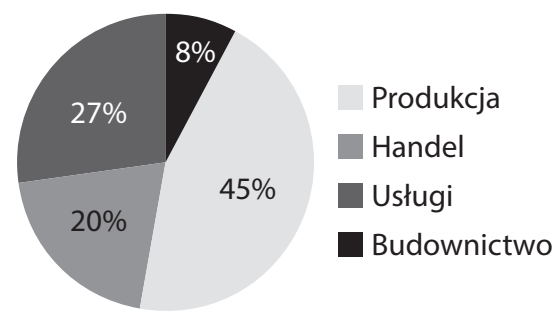

Rysunek 1. Struktura próby dla średnich przedsiębiorstw, określona warstwowo na podstawie danych o populacji z 2017 roku Źródło: opracowanie własne na podstawie wyników badań ankietowych.

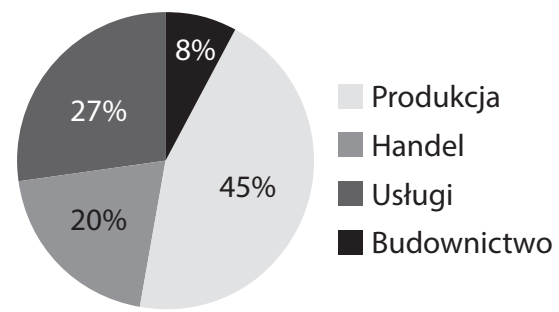

Rysunek 2. Struktura próby dla dużych przedsiębiorstw, określona warstwowo na podstawie danych o populacji z 2017 roku

Źródto: opracowanie własne na podstawie wyników badań ankietowych.

\section{Wykorzystane metody badawcze i postawione problemy badawcze}

Na etapie gromadzenia wyników badań wykorzystano kwestionariusz ankietowy, w którym pięć kolejnych stwierdzeń odnosiło się do behawioralnych aspektów zarządzania ryzykiem, obejmujących scharakteryzowane we wprowadzeniu: 
- postrzeganie ryzyka,

- skłonność do podejmowania ryzyka,

- postawy wobec ryzyka.

Pierwsze ze stwierdzeń dotyczyło postrzegania ryzyka i zidentyfikowania, w jakim stopniu kojarzone jest ono z sytuacją zagrożenia i możliwością ponoszenia strat. Drugie pozwoliło ocenić skłonność do podejmowania ryzyka przez menedżerów w przedsiębiorstwach, a trzy kolejne nawiązywały do postaw wobec ryzyka (jedno z nich miało charakter ogólny, a dwa następne dotyczyły określenia poziomu potencjalnej awersji do ryzyka wewnętrznego i zewnętrznego). Zestaw scharakteryzowanych stwierdzeń przedstawiał się następująco:

- Ryzyko w przedsiębiorstwie kojarzone jest przede wszystkim z zagrożeniami.

- Menedżerowie nie lubią i nie chcą podejmować ryzyka.

- Przedsiębiorstwo stara się unikać przedsięwzięć ryzykownych.

- Menedżerowie obawiają się przede wszystkim zagrożeń wewnętrznych.

- Menedżerowie obawiają się przede wszystkim zagrożeń zewnętrznych.

Ankietowani oceniali odpowiedzi w pięciostopniowej skali Likerta, zgodnie z poniższym opisem:

- 1 - Nie dotyczy mojego przedsiębiorstwa.

- 2 - Dotyczy mojego przedsiębiorstwa w niewielkim zakresie.

- 3 - Częściowo dotyczy mojego przedsiębiorstwa.

- 4 - Dotyczy mojego przedsiębiorstwa w znacznym zakresie.

- 5 - W pełni dotyczy mojego przedsiębiorstwa.

Wyniki przeprowadzonych badań pozwoliły odpowiedzieć na następujące pytania badawcze:

- Jakie cechy behawioralne w kontekście zarządzania ryzykiem charakteryzują menedżerów w polskich małych i średnich przedsiębiorstwach?

- Czy istnieją różnice w postrzeganiu, skłonności i postawach wobec ryzyka w średnich i dużych przedsiębiorstwach w Polsce?

W opracowaniu wyników i udzieleniu odpowiedzi na wskazane problemy badawcze wykorzystano test niezależności $\chi^{2}$, testując następujące hipotezy:

$\mathrm{H}_{0}$ : Zmienne X i Y są niezależne.

$\mathrm{H}_{1}$ : Zmienne X i Y nie są niezależne.

Hipoteza $\mathrm{H}_{0}$ jest odrzucana, jeśli wartość obliczonej statystyki $\chi^{2}$ jest większa od statystyki teoretycznej. Jeżeli zaś jest mniejsza, należy przyjąć hipotezę $\mathrm{H}_{0}$. Zakładany w badaniach poziom istotności wyniósł $\alpha=0,05$. Hipotezy testowano w odniesieniu do wielkości badanych przedsiębiorstw (średnie, duże). 


\section{Wyniki badań}

Jak już wspomniano, w przypadku pierwszego stwierdzenia zawartego w ankiecie podjęto próbę określenia, czy i w jakim zakresie ryzyko postrzegane jest jako zagrożenie. Odpowiedzi na to stwierdzenie przedstawiono na rysunku 3.

Wyniki w obu grupach rozkładały się podobnie. Ankietowani, zarówno w małych, jak i dużych przedsiębiorstwach, najczęściej konstatowali, że stwierdzenie o tym, iż ryzyko oznacza zagrożenie, jest częściowo prawdziwe w odniesieniu do reprezentowanych przez nich przedsiębiorstw. Niemniej jednak w średnich przedsiębiorstwach postrzeganie ryzyka było nieco bardziej optymistyczne niż w dużych firmach (około 35\% odpowiedzi 1 i 2, nieidentyfikujących ryzyka z zagrożeniami w średnich przedsiębiorstwach wobec jedynie $27 \%$ takich wskazań w dużych firmach). Mogło to wynikać z dwóch okoliczności. Pierwsza z nich może odnosić się do bogatszej historii doświadczeń charakteryzującej duże podmioty gospodarcze (większa skala działania i większa ekspozycja na ryzyko). Druga może wiązać się z wyższym poziomem wiedzy o istniejących i potencjalnych zagrożeniach w dużych przedsiębiorstwach (wyższe kompetencje menedżerskie, posiadanie wyspecjalizowanych komórek organizacyjnych odpowiedzialnych za zarządzanie ryzykiem), a co za tym idzie - z wyższą obawą przed wystąpieniem negatywnych skutków realizacji ryzyka.

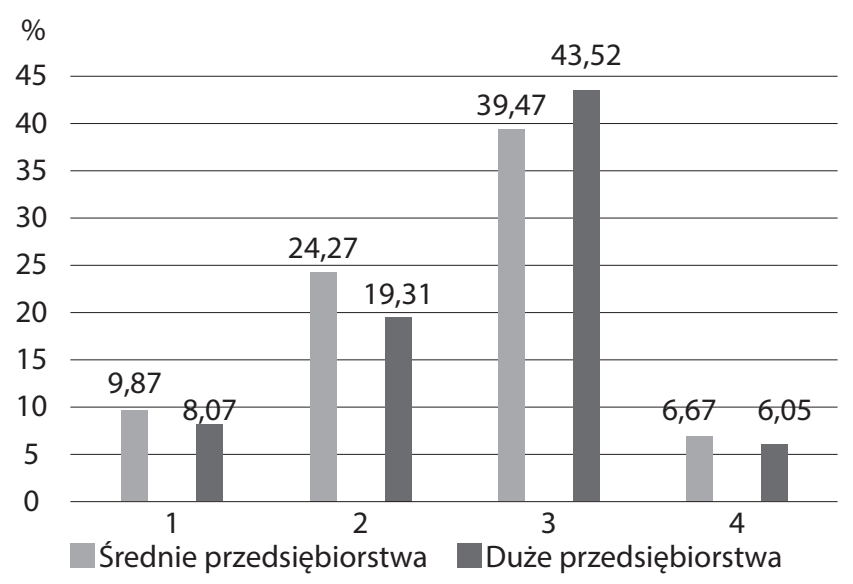

Rysunek 3. Rozkład ocen w przypadku stwierdzenia: „Ryzyko w przedsiębiorstwie kojarzone jest przede wszystkim z zagrożeniami”

Źródło: opracowanie własne na podstawie wyników badań ankietowych.

Wskazane różnice między średnimi a dużymi przedsiębiorstwami w zakresie postrzegania ryzyka nie są jednak istotne statystycznie w świetle przeprowadzonego 
testu $\chi^{2}$ (tabela 1). Można zatem stwierdzić, że w większości średnich i dużych przedsiębiorstw ryzyko częściej jest kojarzone z zagrożeniami i potencjalnymi stratami niż z szansami i możliwością osiągnięcia dodatkowych zysków.

Tabela 1. Wyniki testu $X^{2}$ dla badanych przedsiębiorstw (średnie, duże)

\begin{tabular}{|c|c|c|}
\hline Stwierdzenie & $\begin{array}{l}\text { Statystyka } \\
\text { empiryczna }\end{array}$ & $\begin{array}{l}\text { Statystyka } \\
\text { teoretyczna }\end{array}$ \\
\hline $\begin{array}{l}\text { Ryzyko w przedsiębiorstwie kojarzone jest przede wszystkim } \\
\text { z zagrożeniami. }\end{array}$ & 4,4242 & \multirow[t]{5}{*}{9,4877} \\
\hline Menedżerowie nie lubią i nie chcą podejmować ryzyka. & 1,4966 & \\
\hline Przedsiębiorstwo stara się unikać przedsięwzięć ryzykownych. & 2,5944 & \\
\hline $\begin{array}{l}\text { Menedżerowie obawiają się przede wszystkim zagrożeń } \\
\text { wewnętrznych. }\end{array}$ & $14,9437^{\star}$ & \\
\hline $\begin{array}{l}\text { Menedżerowie obawiają się przede wszystkim zagrożeń } \\
\text { zewnętrznych. }\end{array}$ & $11,5701^{*}$ & \\
\hline
\end{tabular}

Źródło: opracowanie własne na podstawie wyników badań ankietowych.

Drugie stwierdzenie miało na celu ocenę skłonności wobec ryzyka poprzez określenie, w jakim stopniu ankietowani identyfikują się ze stwierdzeniem: „Menedżerowie nie lubią i nie chcą podejmować ryzyka”. Rozkład odpowiedzi na to stwierdzenie przedstawiono na rysunku 4.

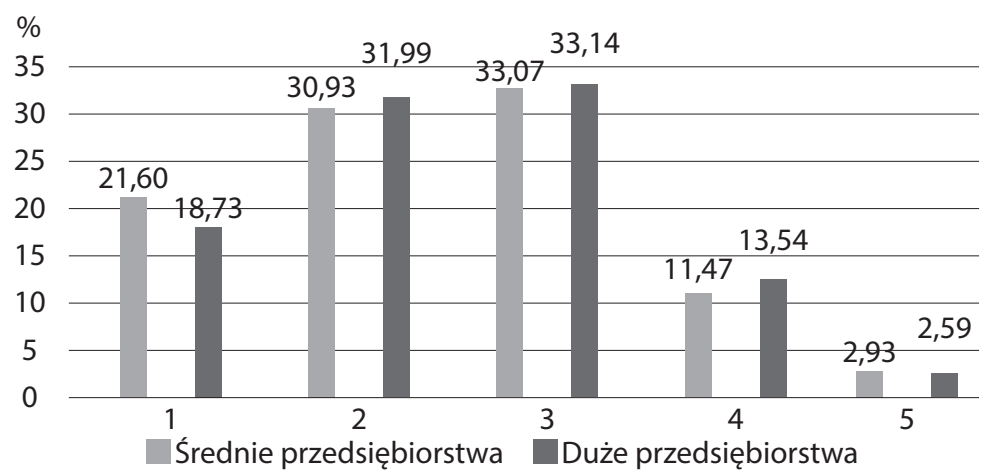

Rysunek 4. Rozkład ocen w przypadku stwierdzenia: „Menedżerowie nie lubią i nie chcą podejmować ryzyka"

Źródło: opracowanie własne na podstawie wyników badań ankietowych.

W przypadku tego stwierdzenia rozkład odpowiedzi dla średnich i dużych przedsiębiorstw przedstawia się bardzo podobnie. Potwierdza to także test $\chi^{2}$, zgodnie z którym w wypadku deklarowanej skłonności do ryzyka nie istnieją 
istotne statystyczne różnice między badanymi grupami podmiotów. Ankietowani w obu zbiorowościach stwierdzili, że menedżerowie w ich przedsiębiorstwach nie obawiają się ryzyka i chcą je podejmować (ponad 51\% odpowiedzi 1 i 2, nieidentyfikujących się z opisem stwierdzenia w wypadku średnich firm i ponad $50 \%$ takich wskazań w dużych przedsiębiorstwach). Mniej więcej jedna trzecia badanych w obu przypadkach odpowiedziała też, że stwierdzenie o nielubieniu i niepodejmowaniu ryzyka dotyczy ich jedynie częściowo. Wyniki badań potwierdzają wysoką skłonność do podejmowania nowych, często ryzykownych wyzwań zarówno w średnich, jak i dużych przedsiębiorstwach, co pozytywnie świadczy o poziomie przedsiębiorczości w badanych podmiotach. Pozwala także ocenić ich skłonność do ryzyka jako typową i charakterystyczną dla osób przedsiębiorczych.

W świetle powyższego warto ocenić również, czy skłonność do ryzyka wpływała na postawy średnich i dużych przedsiębiorstw wobec ryzyka. Identyfikacja tych postaw została przeprowadzona w ramach trzeciego stwierdzenia zawartego w ankiecie, a rozkład wskazań ankietowanych w tym przypadku przedstawiono na rysunku 5. Zgodnie z zaprezentowanymi na rysunku danymi wysoka akceptacja i skłonność do podejmowania ryzyka nie znalazły już tak wyraźnego odzwierciedlenia w postawach wobec ryzyka, i to zarówno w średnich, jak i dużych przedsiębiorstwach. Zgodność odpowiedzi w tym zakresie między średnimi i dużymi podmiotami potwierdza także wynik testu $\chi^{2}$ (tabela 1). Mimo ponad 50-procentowej skłonności do podejmowania ryzyka jedynie około $27 \%$ ankietowanych w średnich i 32\% w dużych przedsiębiorstwach zadeklarowało wyraźną tendencję do unikania ryzyka (odpowiedzi 4 i 5), a jedynie mniej więcej jedna trzecia stwierdziła, że unikanie ryzyka nie dotyczy ich w ogóle lub dotyczy w niewielkim zakresie (odpowiedzi 1 i 2).

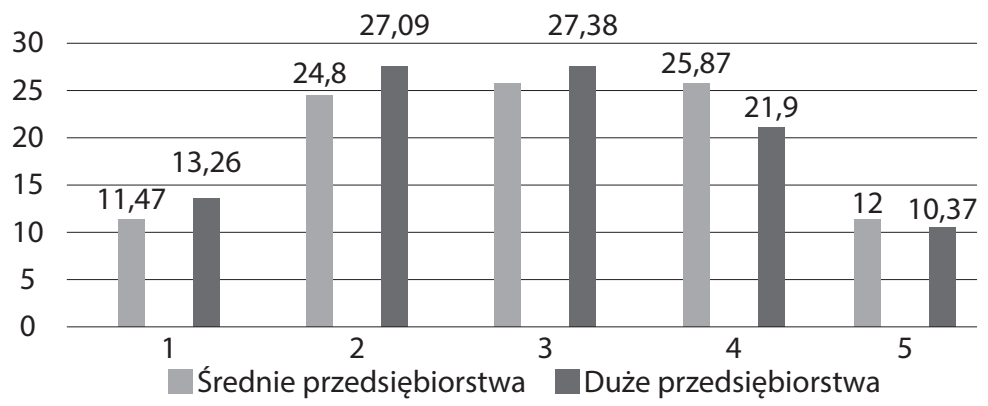

Rysunek 5. Rozkład ocen w przypadku stwierdzenia: „Przedsiębiorstwo stara się unikać przedsięwzięć ryzykownych" Źródło: opracowanie własne na podstawie wyników badań ankietowych. 
Można zatem zauważyć, że skłonność do ryzyka nie przełożyła się bezpośrednio na postawy wobec ryzyka - i to w obu badanych grupach. Deklarowana skłonność do podejmowania ryzyka była zdecydowanie wyższa niż ostateczna chęć realizacji działań obarczonych ryzykiem. Takie postawy niewątpliwie wiążą się ze zidentyfikowanym wcześniej postrzeganiem ryzyka jako zagrożenia, co w dużej mierze warunkuje ostateczną decyzję o podjęciu lub uniknięciu ryzyka. Potwierdza to także zbliżony rozkład odpowiedzi na ankietowe stwierdzenia 1 i 3 .

Dwa kolejne stwierdzenia umożliwiły hierarchizację rodzaju ryzyka i określenie, które budzi w ankietowanych największe obawy i niepokój. Rozkład odpowiedzi na nie przedstawiono na rysunkach 6 i 7. Większość ankietowanych w średnich i dużych przedsiębiorstwach (łącznie ponad 65\% w średnich podmiotach i ponad $52 \% \mathrm{w}$ dużych firmach) stwierdziła, że obawa przed zagrożeniami wewnętrznymi ich nie dotyczy lub dotyczy w bardzo małym zakresie (odpowiedzi 1 i 2). W przypadku dużych przedsiębiorstw wyraźnie zaznaczył się także udział stwierdzeń o częściowej obawie przed zagrożeniami wewnętrznymi (ponad 33\%). Znaczna część ankietowanych przypisała im również zdecydowanie wyższą rangę (odpowiedzi 4 i 5 - łącznie ponad 13\%), niż miało to miejsce w przypadku ankietowanych w średnich podmiotach (odpowiedzi 4 i 5 - łącznie ponad 9\%).

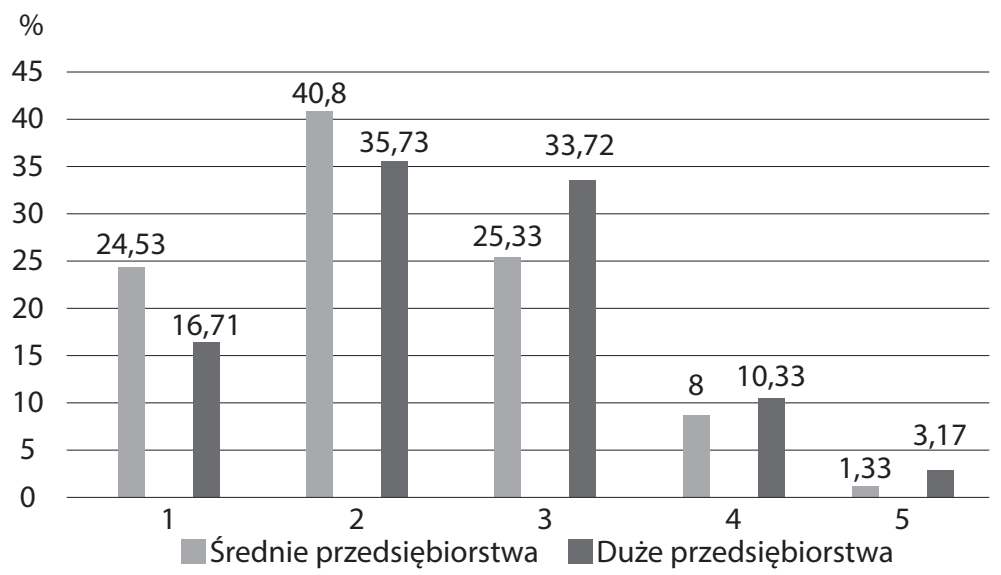

Rysunek 6. Rozkład ocen w przypadku stwierdzenia: „Menedżerowie obawiają się przede wszystkim zagrożeń wewnętrznych”

Źródło: opracowanie własne na podstawie wyników badań ankietowych.

Wskazane obserwacje potwierdzają też dane przedstawione na rysunku 7. Zagrożenia zewnętrzne budziły większe obawy niż niebezpieczeństwa wewnętrzne w średnich przedsiębiorstwach (ponad $41 \%$ odpowiedzi 4 i 5 oraz ponad $30 \%$ odpowiedzi 3). W dużych firmach poziom niepokoju wobec zagrożeń zewnętrznych 
i wewnętrznych był rozłożony bardziej równomiernie, choć i w tym przypadku można zauważyć dominację lęku przed niebezpieczeństwem zewnętrznym. Niemniej jednak dominacja ta nie jest tak znaczna jak w wypadku średnich przedsiębiorstw. Zaistniałe różnice między średnimi a dużymi podmiotami potwierdza także test $\chi^{2}$, który w przypadku obu opisywanych stwierdzeń nakazuje odrzucenie hipotezy $\mathrm{H}_{0}$ o niezależności badanych zmiennych.

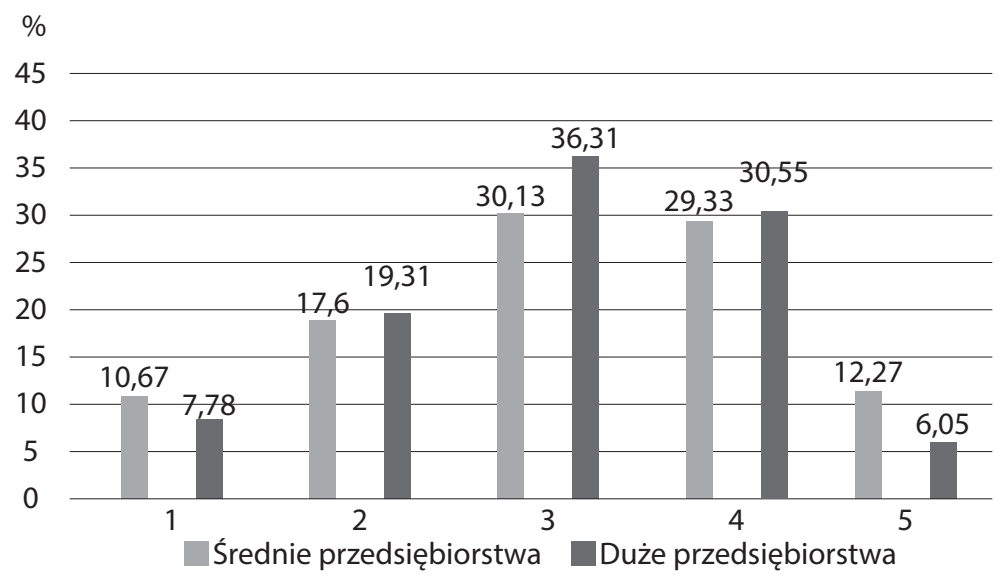

Rysunek 7. Rozkład ocen w przypadku stwierdzenia: „Menedżerowie obawiają się przede wszystkim zagrożeń zewnętrznych"

Źródto: opracowanie własne na podstawie wyników badań ankietowych.

W świetle powyższego można stwierdzić, że średnie przedsiębiorstwa mniej obawiają się wewnętrznych źródeł ryzyka, co może wynikać zarówno z mniejszej liczby zasobów i procesów mogących te źródła uaktywniać, jak i ze słabszej pozycji konkurencyjnej, związanej z mniejszymi rozmiarami prowadzonej działalności, a co za tym idzie - niższą odpornością na ryzyko generowane przez otoczenie bliższe (konkurencyjne) i dalsze (ogólnogospodarcze).

\section{Zakończenie}

Odpowiadając na postawione w artykule pytania badawcze, należy w pierwszej kolejności stwierdzić, że zarówno średnie, jak i duże przedsiębiorstwa postrzegały ryzyko przede wszystkim jako zagrożenie, a zatem zgodnie z defensywną koncepcją definiowania ryzyka i wbrew lansowanej przez Druckera tezie, że podejmowanie ryzyka oznacza także szansę na dodatkowy zysk, a nie jedynie możliwość poniesienia nieprzewidywanej straty. Takie postrzeganie ryzyka może stanowić destymulantę dla zachowań i działań przedsiębiorczych. U podstaw tak zidentyfikowanej 
percepcji ryzyka może leżeć znaczna zmienność uwarunkowań prowadzenia działalności gospodarczej i stosunkowo krótki okres obowiązywania zasad wolnorynkowych w polskiej gospodarce.

Trzeba jednak dodać, że ankietowani - zarówno w średnich, jak i dużych przedsiębiorstwach - deklarowali wysoką skłonność do podejmowania ryzyka, w większości (ponad 50\%) stwierdzając, że w reprezentowanych przez nich firmach menedżerowie lubią i podejmują ryzyko, co teoretycznie sprzyja rozwojowi postaw przedsiębiorczych. Tak oceniona skłonność do podejmowania ryzyka znalazła jednak wyłącznie częściowe potwierdzenie w zidentyfikowanych postawach wobec ryzyka, ponieważ już tylko mniej więcej jedna trzecia badanych przedsiębiorstw stwierdziła, że nie unika ryzyka w toku swojej działalności.

W ramach prowadzonych badań nie stwierdzono istotnych statystycznie różnic w głównych behawioralnych aspektach zarządzania ryzykiem między średnimi i dużymi przedsiębiorstwami. Jedyna zidentyfikowana i istotna statystycznie różnica dotyczyła hierarchii obaw przed ryzykiem. Dla średnich podmiotów zdecydowanie większe zagrożenia wiązały się z ryzykiem zewnętrznym niż wewnętrznym. Natomiast $\mathrm{w}$ dużych firmach obawy przed oboma rodzajami ryzyka były bardziej zrównoważone, $\mathrm{z}$ nieznaczną dominacją lęku przed niebezpieczeństwami związanymi z ich otoczeniem.

Przeprowadzone na potrzeby artykułu badania ankietowe pozwoliły na ocenę postrzegania ryzyka, skłonności do ryzyka i postaw wobec ryzyka w grupie średnich i dużych przedsiębiorstw w Polsce. Umożliwiły także wskazanie różnic $\mathrm{w}$ zakresie wymienionych behawioralnych aspektów zarządzania ryzykiem między średnimi i dużymi podmiotami. We wskazanym kontekście stanowią one poznawcze uzupełnienie wiedzy z zakresu uwarunkowań zarządzania ryzykiem w polskiej rzeczywistości gospodarczej. Dalsze badania empiryczne powinny być zatem ukierunkowane na określenie wpływu czynników behawioralnych na proces podejmowania decyzji w zakresie zarządzania ryzykiem oraz skuteczność i efektywności tych decyzji. 
Bibliografia

Arena M., Arnaboldi M., Azzone G., The organizational dynamics of enterprise risk management, „Accounting, Organizations and Society” 2010, vol. 35, no. 7, s. 659-675.

Bromiley Ph., McShane M., Nair A., Rustambekov E., Enterprise risk management: Review, critique, and research directions, „Long Range Planning” 2014, vol. 11, s. 1-12.

Douglas E.J., Perceptions - looking at the world through entrepreneurial lenses, [w:] A.L. Carsrud, M. Brännba (red.), Understanding the Entrepreneurial Mind: Opening the Black Box, Springer, New York 2009, s. 5-25.

Drucker P.F., Skuteczne zarzqdzanie, PWN, Warszawa 1976.

Drucker P.F., Zarzq̨dzanie organizacją pozarządowq. Teoria i praktyka, Wydawnictwo Borodo, Warszawa 1995.

Durst S., Hinteregge Ch., Zieba M., The linkage between knowledge risk management and organizational performance, „Journal of Business Research” 2019, vol. 105, s. 1-10.

Isen A.M., Baron R.A., Positive effect as a factor in organizational behaviour, „Research in Organizational Behavior" 1991, vol. 13, s. 1-53.

Isen A.M., Geva N., Influence of positive effect on the subjective utility of gains and losses: It is just not worth the risk, „Journal of Personality and Social Psychology” 1988, vol. 55, s. 710-717.

Jajuga K., Jajuga T., Inwestycje. Instrumenty finansowe, ryzyko finansowe. Inżynieria finansowa, Wydawnictwo Naukowe PWN, Warszawa 1998.

Jaramillo M., Vargas K.L., Interpersonal comparisons and risk attitudes: An artefactual field experiment, „Economics Letters” 2019, vol. 179, s. 16-18.

Jędralska K., Zachowania przedsiębiorstw w sytuacjach niepewnych i ryzykownych, Wydawnictwo Akademii Ekonomicznej w Katowicach, Katowice 1992.

Kaczmarek T.T., Ryzyko i zarządzanie ryzykiem. Ujęcie interdyscyplinarne, Wydawnictwo Difin, Warszawa 2007.

Karmańska A., Neoklasyczne ramy analizy atrybutów ryzyka, [w:] A. Karmańska (red.), Ryzyko w rachunkowości, Wydawnictwo Difin, Warszawa 2008, s. 24-30.

Lofstedt B.R., Wardman J., The changing nature of communication and regulation of risk in Europe, „Journal of Risk Research” 2011, vol. 14, issue 4, s. 409-429.

Malik M.F., Zaman M., Buckby S., Enterprise risk management and firm performance: Role of the risk committee, „Journal of Contemporary Accounting \& Economics” 2020, vol. 16, issue 1, nr art. 100178.

McShane M.K., Nair A., Rustambekov E., Does enterprise risk management increase firm value?, „Journal of Accounting, Auditing \& Finance” 2011, vol. 26, no. 4, s. 641-658.

Nax H.H., Newton J., Risk attitudes and risk dominance in the long run, „Games and Economic Behavior" 2019, vol. 116, s. 179-184.

Tausch F., Zumbuehl M., Stability of risk attitudes and media coverage of economic news, „Journal of Economic Behavior \& Organization" 2018, vol. 150, s. 295-310.

Tavor T., The theoretical attitude and actual behavior of an individual towards risk, „Journal of Behavioral and Experimental Finance" 2019, vol. 23, s. 1-11.

Thamhain H., Managing risks in complex projects, „Project Management Journal” 2013, vol. 44, s. 20-35. 


\section{Streszczenie}

Głównym celem artykułu jest identyfikacja i charakterystyka czynników behawioralnych w zarządzaniu ryzykiem w polskich przedsiębiorstwach, przeprowadzona na podstawie badań ankietowych na reprezentatywnej, losowo wybranej próbie średnich i dużych przedsiębiorstw (łącznie 722 podmioty) w 2019 roku. Analizie poddaje się kolejno postrzeganie ryzyka, skłonność do podejmowania ryzyka oraz postawy wobec ryzyka charakteryzujące zarządzających badanymi przedsiębiorstwami. Z badań wynika, że polskie średnie i duże firmy postrzegają ryzyko głównie jako zagrożenie. Charakteryzuje je także wysoka deklaratywna skłonność do podejmowania ryzyka, która nie znajduje jednak bezpośredniego odzwierciedlenia w postawach wobec ryzyka (dominuje unikanie ryzyka).

Słowa kluczowe: zarządzanie ryzykiem, postrzeganie ryzyka, skłonność do ryzyka, postawy wobec ryzyka, ryzyko w polskich średnich i dużych przedsiębiorstwach

\section{Behavioural aspects of risk management in polish enterprises based on surveys' results}

\section{Abstract}

The main purpose of the article is to identify and characterize behavioural factors in risk management in Polish enterprises based on surveys carried out on a randomly selected research sample (722 medium and large enterprises) in 2019. The risk perception, risk appetite and risk attitudes characterizing the managers of the surveyed enterprises are successively analysed. Research shows that Polish medium and large enterprises perceived risk mainly as a threat. They are also characterized by a high declarative risk appetite, which is not directly reflected in risk attitudes (high domination of risk avoidance).

Keywords: risk management, risk perception, risk appetite, risk attitudes, risk in Polish medium and large enterprises

Jakub Drzewiecki ${ }^{11}$

11 Dr Jakub Drzewiecki - Uniwersytet Ekonomiczny we Wrocławiu, Wydział Zarządzania, Katedra Teorii Organizacji i Zarządzania. 